\title{
URBANISMO BARROCO EN LIMA VIRREINAL: HACIA LA RECUPERACION DE LA CALLE DE LA AMARGURA ${ }^{1}$
}

\author{
BAROQUE URBANISM IN VIRREYNAL LIMA: TO RECOVERY THE STREET OF SORROW
}

\author{
MARÍA ESTHER RÍOS FIGUEROA ${ }^{2}$ \\ Fecha de recepción: 25 de junia de 2014. \\ Fecha de aprobación: 28 de agasto de 2014.
}

\section{RESUMEN}

En la búsqueda de ejemplos concretos de urbanismo barroco entre los años 1571 y 1746, encontramos una calle en particular llamada calle de la Amargura (hoy jirón Camaná), nombre con el que se identificaba a las nueve cuadras que distanciaban el Convento Grande de Santo Domingo de su Recolección. Los escasos trabajos sobre Urbanismo Barroco presentan opiniones divergentes respecto a la existencia de un urbanismo barroco en Lima y en Hispanoamérica. El primero en abordar el tema fue Mattos Cárdenas (1980) quien enfoca un urbanismo barroco, en especial en el caso de Lima, sin mencionar aún la calle de la Amargura. San Cristóbal (1986) opina que apenas hay rastros de un urbanismo propiamente barroco en Lima virreinal, y que el barroco se expresa más bien en la arquitectura. Otros investigadores como Rodríguez Camilloni (1999) afirma que los pocos ejemplos de urbanismo barroco los encontramos mas bien en el siglo XVIII, con la construcción por ejemplo de la Navona de Lima (Paseo de Aguas). Explicar el proceso de la calle de la Amargura contribuirá a conocer la historiografía urbana que conllevará asimismo a valorar mejor y recuperar el patrimonio urbanístico virreinal de la ciudad de Lima.

\section{PALABRAS CLAVE}

Urbanismo barroco, historia urbana, calles de Lima.

\begin{abstract}
In the search of concrete examples of baroque urbanism between the years 1571 and 1746, we find a particular street called the street of Sorrow (today known as Jr. Camaná), name with which are identified the nine blocks that separate the Great Convent of Saint Dominic of its Recolección. The lack of works of the Baroque Urbanism present divergent opinions about the existence of a baroque urbanism in Lima and in Spanish America. The first to adress the issue was Mattos Cárdenas (1980) who focuses Baroque urbanism, especially in the case of Lima, withhout even mentioning the street of Sorrow. San Cristobal (1986) thinks that there are barely tracks of a properly baroque urbanism in viceregal Lima, and that the baroque expresses itself better in architecture. Other researchers such as Rodríguez Camilloni (1999) affirm that the few examples of baroque urbanism are better found in the XVIII century, for example with the construction of the Navona de Lima (Paseo de Aguas). To explain the process of the street of Sorrow will contribute to shed light on this chapter of the urban historiography and will also entail a better appreciation and recovery of the urban viceregal patrimony of the city of Lima.
\end{abstract}

\section{KEYWORDS}

Baroque Urbanism, Urban History, streets of Lima.

\footnotetext{
1. El presente artículo se basa en la tesis para optar el grado de Maestro en Ciencias otorgada, en el año 2012, por la Universidad Nacional de Ingeniería, con mención en Restauración de Monumentos en Arquitectura y Urbanismo, titulada: Urbanismo Barroco, conventualización y crecimiento urbano en Lima Virreinal: La calle de la Amargura 1571 - 1746.

2. Arquitecta egresada de la Universidad Ricardo Palma, con 20 años de experiencia. Maestro en Ciencias con mención en Restauración de Monumentos en Arquitectura y Urbanismo otorgado por la Universidad Nacional de Ingeniería. Es miembro activo del Consejo Internacional de Monumentos y Sitios - ICOMOS - ICOMOS PERU y se ha desempeñado profesionalmente en instituciones del Estado. En la actualidad, se encuentra a cargo de la Coordinación de Registro e Investigación Histórica de la Dirección de Patrimonio Histórico Inmueble del Ministerio de Cultura del Perú. (mariaestherios@hotmail.com).
} 
Este artículo pretende explicar las características del urbanismo barroco limeño y determinar las pautas de diseño urbano que lo relacionan con la Calle de la Amargura, que es la recta que va del Convento de Santo Domingo a la Recolección Santa María Magdalena de la misma orden, actual jirón Camaná del Cercado de Lima.

¿Cuál es la contribución al urbanismo limeño de la recta de Santo Domingo que en el siglo XVII llevó el nombre de Calle de la Amargura?

\section{Del periodo de estudio}

La creación de repúblicas de indios y repúblicas españolas, fruto de las reducciones impuestas por la monarquía española caracteriza el periodo de estudio del mestizaje cultural y el predominio de una transferencia religiosa que explica su trascendencia en el barroco hispanoamericano. Al respecto, hay que precisar que el periodo de estudio entre 1571 y 1746 no establece que este sea el inicio y el fin del barroco en Lima. El barroco no hace más que acumular para sí las experiencias de los años que la anteceden. Si está reconocido por la mayoría de los investigadores o estudiosos sobre el tema que el barroco se inicia en el siglo XVII. Para su entendimiento, se hace necesario conocer qué circunstancias contribuyeron a su establecimiento en las diversas manifestaciones del quehacer humano, tangible e intangible. En este artículo, se enfatiza el aspecto urbanístico que entraña de manera indisoluble su forma y su función urbana.

El padre Javier del Río pone de manifiesto que la sacralización de los diversos ámbitos sociales, propia del barroco y del espíritu del Concilio de Trento, encontró puntos de coincidencia con algunas tradiciones de las comunidades indígenas. Así, en las primeras comunidades eclesiales que surgieron en el Perú,

[...] la vida diaria, todas sus manifestaciones, la naturaleza, el espacio, el uso de los espacios abiertos adquirían un sentido religioso y se traducían en multitud de obras de arte, tanto efímero como permanente, en fiestas y en música. El barroco integró el urbanismo y la arquitectura, la escultura y la pintura, la orfebrería y los tejidos, el teatro y la danza, la religiosidad popular y la liturgia oficial romana.(Rio, 2008, pp.483, 484).

Es por ello que en América el tiempo barroco marcó su propio ritmo, determinando el desarrollo de unos mecanismos de persuasión y sacralización. El periodo de estudio abarca desde el año 1571 y, como veremos más adelante, en el caso de Lima, desde el momento en que se fundó el Cercado de Indios, en 1571, hasta el siglo XVIII, año 1746, marcado por el terremoto que sacudió la ciudad de Lima y El Callao.

La historia de la ciudad es un proceso y una continuidad; la secuencia de hechos históricos y realizaciones urbano arquitectónicas lo confirman. Distinguimos como hitos o puntos de quiebre los hechos importantes que marcaron de forma indeleble la ciudad. En un caso, son resultado de un proceso que deviene de gestiones anteriores, como fue la fundación de reducciones indígenas y en otro caso, por hechos naturales que de algún modo también fueron consecuencia de la formación natural del territorio, cuyo conocimiento se fue adquiriendo según se fueron experimentando, por ejemplo, los sismos que asolaron la ciudad desde sus inicios.

\section{La formación del Pueblo de Indios del Cercado}

El modelo bíblico estudiado detalladamente por Mattos-Cárdenas está enmarcado por el Segundo Concilio Provincial de Lima, celebrado en 1567 y en 1568, tras los alcances de la Reforma Católica impulsada por el Concilio de Trento (1545-1563) en el que se establece que los indios que vivían dispersos fuesen reducidos a pueblos, concentrándolos en reducciones y organizándolos en parroquias cada 400 personas; pero, es en la Constitución 82 de la primera parte que establece que se funden también pueblos de indios en la periferia de las ciudades españolas.

Es entonces que se dio cumplimiento a la Constitución 82, primera parte del Segundo Concilio Provincial de Lima. Así, se reúne a los indios en un pueblo en la periferia de la ciudad y tomó el nombre de Santiago, aunque fue conocido como pueblo cercado de indios.

El arquitecto Leonardo Mattos-Cárdenas sostiene que la concepción y trazado original del Cercado de Indios refleja la morfología de la Jerusalén Celeste que aparece por primera vez en el cuadro de Martín de Vos, pues coinciden cronológicamente la idealización pictórica y la materialización urbana fechada en 1571. En efecto, el perímetro cercado y trazado vial va dirigido a los cuatro puntos cardinales, orientación característica de la Ciudad de Dios y sus 36 manzanas divididas en cuatro solares. Mattos-Cárdenas es de opinión que la retórica barroca forzó interpretaciones a posteriori sobre el modelo bíblico que representa el Pueblo de Indios del Cercado. 
Por otra parte, el dominico Juan Meléndez expresó en su crónica que:

La ciudad que vio San Juan en su Apocalipsis estaba puesta en cuadro y la ciudad de Lima está compuesta en cuadras y aunque aquella era del cielo y ésta de la Tierra -diferencia que las distingue mucho- la figura por lo menos es la misma, en partes de la gran ciudad de Los Reyes y en todo en la Jerusalén Revelada y ya que se parecen en la forma bien puede presumirse que la diseñó Dios para que la fundasen los españoles por cabeza de las nuevas tierras y cielos que se descubrieron y conquistaron. Es pues la planta de la ciudad de Lima perfectísima[...] (Melendez, 1681).

Si bien Meléndez está refiriéndose a la ciudad de Lima, es importante señalar que para el año de 1681, en pleno apogeo del barroco, se asocia la idea de la Jerusalén Revelada, imagen empleada para la formación del Pueblo del Cercado de Indios, noventa años antes.

\section{El terremoto de 1746}

Sendas relaciones dan cuenta de lo acaecido aquel fatídico 28 de octubre de 1746 que dejó a la ciudad de Lima casi reducida a polvo. ¿Cómo llegó la ciudad antes de la catástrofe?

Había llegado Lima al punto de perfección de que era capaz una ciudad de las distancias de este nuevo mundo [...] se adornaban sus bien regladas calles de toda la hermosura que contribuye la proporción, satisfaciendo al gusto y comodidad con todo el ornato y primor de la mejor arquitectura, y con la alegría de muchas vistosas fuentes, a que por acueductos subterráneos se conducía el agua: y en la elevación de sus templos, y construcción de los religiosos conventos, y monasterios a que el celo del culto encendía una devota confianza que no atendía a los riesgos, puede decirse que su magnificencia, sino excedía pudiera hacer competencia a las más grandes fábricas de este género en todo el mundo; pues la hermosura de sus fachadas, sus vestíbulos y cementerios, la grandeza de sus naos (naves), sus claustros y escaleras, nada hacían envidiar de amplitud y belleza. Setenta y cuatro grandes y pequeñas iglesias se numeraban con las capillas públicas; catorce monasterios, y otros tantos hospitales y recogimientos, y en ellas era igual la riqueza y perfección, así como los retablos y pinturas, como en los adornos de muebles, lámparas, vasos de plata, y exquisitas obras de oro, perlas y fina pedrería en las custodias, coronas y joyas (Odriozola, 1863).

Esta es la descripción de la ciudad barroca, tal como nos relató Manuel de Odriozola. Lima devota, "sembrada" de iglesias, con cursos de aguas en sus rectas calles y fuentes. A decir del relator, todo quedó reducido a polvo.
A continuación, describiremos el llamado modelo urbano barroco o urbanismo barroco limeño no sin antes aproximarnos a su conocimiento tanto en el ámbito europeo como en el hispanoamericano.

\section{Urbanismo barroco}

El barroco necesitaba para su arraigo, difusión y expresión la previa existencia de un ámbito urbano complejo y organizado así como del templo en sus portadas y retablos o de sus calles. Como alguna vez lo señaló Esteanez Álvarez, en el barroco: "el trazado viario y la arquitectura fueron pensados de acuerdo con las necesidades de la ciudad convertida en un cuerpo místico estructurado por los centros o puntos de atracción eclesiásticos."

\subsection{Urbanismo barroco europeo}

En el periodo barroco, por toda Europa, se ampliaron los palacios urbanos, edificios públicos e iglesias como las grandes bóvedas de la nueva basílica de San Pedro en Roma y la catedral de San Pablo en Londres. Estas fueron el centro de composiciones monumentales en las calles y plazas. El gobierno veneciano transformó el mercado medieval en la plaza de San Marcos en un espacio majestuoso.

Lewis Mumford consideraba a las avenidas: "símbolos importantes y factores clave de la ciudad barroca". Su rígida geometría podía controlar el espacio urbano. Como ejemplos pueden citarse, en Roma, la plaza del Pueblo, donde tres nuevas calles daban forma a una entrada triunfal en el centro de la ciudad. Asimismo, los Campos Elíseos, inaugurados en 1660, abrían una ruta procesional apropiada al rey francés durante sus viajes desde Louvre a uno u otro palacio de veraneo o a los campos de caza.

Se aceptó la idea de ver la ciudad como un escenario. Otras ciudades realizaron cambios masivos en sus perímetros. Interesadas más en la autodefensa ciudades como Viena, Ginebra y Amberes reconstruyeron sus murallas para incluir salientes elaboradas y baluartes en forma de estrella.

Así como Versalles, San Petersburgo surgió por voluntad real y con un claro propósito político como fue la modernización de Rusia. Su apariencia visual fue determinada por los bienes de la corte rusa, de los palacios gubernamentales, los edificios administrativos y las murallas alineadas a la rivera. Este estilo fomentó la vanidad del monarca ruso mientras se 
reafirmaba la existencia de un monopolio de poder y abundancia.

La impaciencia del monarca por expresar con símbolos visuales su poder sobre la comuna civil contribuyó a un proceso de diferenciación espacial, en las principales ciudades europeas. Los grandes proyectos barrocos de las residencias reales europeas fueron construidos durante el siglo XVIII.

Nuevamente retomamos lo señalado por Giulio Carlo Argan: es en Europa que el ideal religioso se convierte en un ideal cívico en contraposición a lo que sucedía en América donde primaba lo religioso.

Para W. Weisbach, el barroco es sobre todo expresión de emociones y vivencias religiosas, lo que lo lleva a afirmar que el barroco es el arte de la Contrarreforma. Sin embargo, si para Europa la meta era el fortalecimiento de la Iglesia Católica, con su conversión a un ideal cívico para expresar el poder los monarcas, en Hispanoamérica la meta en definitiva era la evangelización de la fe católica y tuvo su expresión al modo colonial, sin más paralelos.

\subsection{Urbanismo barroco hispanoamericano}

En la actualidad, se mantiene la opinión de los especialistas que la estructura urbana de la mayoría de las ciudades hispanoamericanas, en los siglos XVII y XVIII, mantuvo como modelo el tipo urbano de cuadrícula simple del siglo XVI.

Una vez establecida la monarquía española se aseguró la continuidad de la red viaria reticular que era prolongada a medida que la ciudad se ensanchaba eliminando rigurosamente todo edificio que quedase fuera de alineación. En 1551, en Lima, las autoridades declaraban:

Puesto que existen muchas calles en esta ciudad con edificios construidos y solares cercados que perjudican a aquellas, en tanto que algunos se imponen a ellas y otros obstruyen su alineación sin mantener el orden previsto en el plano de la ciudad no queda otro remedio que demoler los edificios que obstaculicen la prolongación de las calles ya que, de no hacerlo, ocasionaría grandes perjuicios al plano de la ciudad y a la red viaria (Morris, 1979).

La ciudad hispanoamericana consolidó en el siglo XVI un tipo nítidamente definido por su estructura física en cuadricula, sin acentos ni contrastes y con un único elemento diferenciado al centro: la plaza central. Dicho tipo se consolidó como modelo en la práctica, pero también en la mente de los hispanoa- mericanos de los siglos siguientes. En el periodo barroco, el crecimiento poblacional, el enriquecimiento funcional y el uso permanente y efímero que se les dio a los espacios conjuntamente con el paisaje urbano resultante de la construcción de edificios barrocos transformó la estructura urbana neutra del siglo XVI en un espacio barroco virreinal. La plaza fue tanto el ámbito de exteriorización del culto, la proyección del interior del templo que sacralizaba el ámbito público. En la plaza mayor, las fiestas solemnes de carácter religioso eran periódicas y se sucedían año tras año.

Fue en el uso que se hizo de la estructura en cuadricula, en las actividades de sus habitantes, en las funciones urbanas, donde se percibe el fundamento barroco de la cultura hispanoamericana en los siglos XVII y XVIII, como sostiene Viñuales. Y añade Nicolini que la vida barroca dejó sus huellas en la forma urbana; escasamente en la estructura urbana, pero sí en el paisaje urbano mediante portadas, los balcones, las torres y hasta los aderezos efímeros de las fiestas que, en ciertos casos quedaron grafica o literariamente registrados.

La fiesta religiosa urbana es ante todo un programa iconográfico que puede reproducir en vivo un modelo que reproduce la composición de un cuadro, retablo o texto con capacidad para reproducir un impacto emocional al punto de lograr la participación totalizadora. Es la manifestación de la maravilla y el poder. Maravilla porque se podía contemplar la ciudad festiva y el poder que organizaba, dirigía, ofrecía y regulaba según los criterios y medios establecidos de la época. Estos medios eran la reconversión del espacio urbano en espacio sobrenatural con la presencia realista de santos, ángeles, divinidades en escenas bíblicas, tanto como del Apocalipsis, la Pasión y pasajes evangélicos. La ciudad de Dios se representaba en las calles de los hombres.

En reiteradas oportunidades Ramón Gutiérrez ha insistido en la escasez de ejemplos barrocos en el urbanismo hispanoamericano. Por lo dicho hasta el momento, pretendemos afirmar que sí existe un urbanismo barroco colonial o hispanoamericano.

Palm se preguntaba sobre la cualidad barroca de la ciudad hispanoamericana; es decir, si era posible señalar elementos urbanos hispanoamericanos que tuviesen carácter barroco, como en Europa occidental. Señala algunos ejemplos: la plaza Mayor de Lima, con los conventos cercanos, concentra un eje de poderes y convierte en un anexo al resto de la ciudad, 
las perspectivas de las calles por la unificación de los edificios, la fachada retablo dominando la plaza y la alameda externa a la ciudad enmarcada por lugares de devoción.

Por su parte, Hardoy sostuvo que no hubo grandes conjuntos urbanos en la ciudad colonial hispanoamericana. Salvo algunos ejemplos menores como el jardín público construido en México o la Alameda de Lima, no rescata obras trascendentales de diseño urbano, ya que no había una Corte ni prelados poderosos interesados en ello, tal vez porque dados los pocos recursos disponibles y el predominio del espíritu mercantil de los grupos dirigentes, estos no sentían la necesidad de embellecer la ciudad.

Mattos-Cárdenas, se mantuvo en la posición de que el urbanismo hispanoamericano, durante los siglos XVII y XVIII, supuso "una predominancia brumadora de modelos pragmáticos [...] y, por lo tanto, no hubo ciudades barrocas." (Con esto hace referencia a Hardoy y Gasparini, que entiende la ciudad como un todo preconcebido). Sin embargo, reconoce aspectos de la ciudad que delatan influencias del bagaje internacional barroco, que en América Latina se manifiesta en la segunda mitad del siglo XVII al distinguir en algunas ciudades, ejes visuales, fondos de perspectiva enfatizados por una iglesia, una fuente, una cruz o el infinito integrándolos a otros ejes y nodos. Fue más fácil llevar estos postulados en los jardines que en el trazado urbano y en las vías semiurbanas que dentro del tejido antiguo.

El medio urbano hispanoamericano lo sintetiza en las siguientes tendencias: el abandono de cánones rígidos, el deseo de dominio de la naturaleza, la exaltación del movimiento, la ostentación y la mayor importancia de lo aparente sobre lo real.

Para Ramón Mujica todo parece confluir en el barroco, pues según señala en su cita:

El cristianismo primitivo, la escolástica medieval y el culto al emperador bizantino, el hermetismo y el neoplatonismo renacentista, la mitología greco-romana, la emblemática simbólica y la ortodoxia doctrinal tridentina asociada a la Compañía de Jesús. Estos sistemas de creencias, de diverso origen y data, conviven sin cancelarse mutuamente. El barroco no sustituye unas tradiciones por otras. Más bien acumula, las superpone creando complejos estratos de contenidos paralelos y simultáneos (Mujica, 2002).
Habiendo repasado el barroco en el ámbito europeo e hispanoamericano, concluimos cuatro pautas generales:

1. La gran escala. El cambio de escala se introdujo en las antiguas ciudades europeas con la aparición de las plazas monumentales. Esta experiencia fue anticipada en el siglo XVI con las plazas mayores españolas. En Hispanoamérica, las plazas tuvieron dimensiones muy superiores a las de las plazas españolas al adoptar una escala desconocida hasta el momento en el viejo continente.

El concepto de infinito. La noción de ciudad abierta al infinito estuvo presente en la idea del modelo de la cuadricula hispanoamericana, como grilla de crecimiento ilimitado hacia todas las direcciones. En contraste con el Renacimiento, que tendía a la permanencia y la inmovilidad de todas las cosas, el barroco manifestó desde sus inicios un preciso sentido de dirección que hubo de afectar a los espacios públicos. Los trazados urbanos en cuadricula permiten vincular visualmente lugares distantes de la ciudad y el territorio. Estas ciudades contrastaban con los trazados de las ciudades medievales europeas.

2. El proyecto urbano total. En Hispanoamérica, el proyecto de ciudad como un todo unitario estuvo presente desde el origen del urbanismo colonizador; así, las ciudades fueron concebidas y materializadas como un proyecto urbano total. En gran parte de las ciudades hispanoamericanas, la trama urbana reticular, las calles rectas y las plazas regulares estuvieron presentes desde su origen, como en su desarrollo y crecimiento posteriores.

3. El gran escenario de la vida urbana. La ciudad como conjunto, una gran escena urbana, con sus plazas, sus calles y su arquitectura conformaba un sistema unitario preparado para el espectáculo barroco.

Dentro del sistema urbano hispanoamericano, las calles tendieron a ser más anchas lo que permitía el paso simultáneo de peatones y jinetes. Especialmente en México y en Lima, el desarrollo del transporte de carruajes requirió de calles de mayor ancho.

De la misma manera, se generaba la proyección del culto interior de los templos hacia el exterior que se engalanaba con las fachadas retablo. Así se definían sus vías sacras y recorridos procesionales con los hitos que marcaban las iglesias, los altares o los retablos efímeros lo que recuperaba la validez de los espacios ceremoniales al aire libre de las antiguas religiones indígenas. 
No es que la ciudad hispanoamericana se haya adelantado a los conceptos que Europa adoptaría durante el periodo barroco. En un ensayo, Moreno y Chiarello se plantean la pregunta: ¿no será que Europa, a lo largo de la Edad Moderna, se fue acercando a algo que España había imaginado y comenzado a ensayar primero en America?

\subsection{Urbanismo barroco limeño}

La ciudad de Lima es reconocida por los estudiosos como modelo clásico de la ciudad hispanoamericana, conocido como modelo pragmático; sin embargo, en su trazado urbano se distinguen fragmentos del trazado preexistente: la cuadricula perfecta, las modificaciones de la cuadricula y la ampliación del trazado fundacional. Partiendo del trabajo de Mattos-Cárdenas en el cual reconoce que durante el barroco se evidencia el despertar de una nueva conciencia estética en la morfología de la ciudad, retomamos los siguientes aspectos a considerar en la caracterización del urbanismo barroco limeño:

\section{Alteraciones del tejido urbano}

Un claro ejemplo (no tomado en cuenta por Mattos-Cárdenas) lo constituye la interrupción de la calle que hoy conocemos como jirón Camaná, que antiguamente tenía el nombre de Calle de la Amargura, que estaba proyectada para continuar el antiguo camino inca (hoy jirón Rufino Torrico), pero que a raíz del pedido de los padres dominicos no pudo continuarse, ya que según consta en el Libro de Cabildos de Lima del año de 1608, querían edificar una iglesia como se puede apreciar en el texto siguiente:

En este Cabildo propuso el dicho diego de la presa que los padres dominicos recoletos desta ciudad trataban y ponian por obra fundar su casa e yglesia en una chacara que llaman de los dominicos questa en el callejón que ba a pachacama y de frente de la calle que sale al dicho callejón fundaban su yglesia de manera que la puerta benia de frente de la misma calle que es la que ba a las casas del alguacil mayor francisco ceberino de torres por cuya causa no se podra el tiempo adelante proseguir con la traza que lleva esta ciudad en su fundacion por atajar la dicha calle con la dicha yglesia que quieren hacer y conbiene que se probea de rremedio / abiendose tratado sobre ellos se cometio a los dichos alcaldes don juan de la cueba y villavicencio y luys rodríguez de la serna para que lo bayan a ver y den su parecer y probean lo que conbenga cerca de lo susodicho que para ello y lo a ello anejo y concerniente se les daba y dio comision bastante en forma cuan bastante de derecho se rrequiere con lo cual se acabo este cabildo y los capitulares que en el se ha- llaron. Lo firmaron.../ ante mi alonso de carrion scrivano de cabildo e publico (Bromley, 1947).

\section{Asimilación de tejidos no ortogonales}

El crecimiento urbano trajo consigo la paulatina asimilación de las tramas viales no ortogonales, preexistentes a la fundación de Lima. Es así que durante el periodo barroco se distinguen asimilaciones que envuelven los primeros monasterios o conventos de monjas, construidos en su origen alejados del centro de la ciudad, como fueron los conventos de la Encarnación y de la Concepción al sur y al este de la ciudad inicial. En segundo término, se van asimilando los trazados que siguen los cursos de agua, como las calles que formaron el barrio de Santa Clara o aquellos sectores de la ciudad que se conformaron respetando caminos prehispánicos que caracteriza el barrio de la Recoleta así como también la conexión con el pueblo del Cercado de Indios con caminos que conducían a la puerta de ingreso a la ciudad.

\section{La construcción de arcos barrocos}

Es el caso del arco del Puente de Piedra, levantado en el siglo XVII que enmarcaba el acceso al barrio de San Lázaro.

Otro caso demostrativo lo constituye la Portada de Guía, mencionada por Bromley cuando describió la muralla de Lima: "Contaba con 34 baluartes y cinco portadas Nuestra Señora de Guía, Maravillas, Callao, Barbones y Martinete, a las que se agregaron después por necesidades de comunicación 6 puertas más". Esta portada estaba ubicada fuera del perímetro de la muralla de Lima y tomaba el nombre de la Recolección Agustina de Nuestra Señora de Guía.

\section{Captura de la naturaleza}

Es el caso tardío de la Navona de Lima. El virrey Amat y Junyent que gobernó la ciudad entre 1761 y 1776 llamó la Navona al espacio urbano que creó en el extremo sur de la Alameda de los Descalzos, formando un ángulo ligeramente obtuso con este hacia el oriente con el fin de evocar, como bien lo señala Humberto Rodríguez Camilloni, los principios de diseño urbano que caracteriza a la Navona romana.

En efecto, el destacado trabajo de Rodríguez Camilloni sobre la Navona de Lima nos describe la concepción urbanística de Amat dirigida a formar un todo armonioso, con la fuente escenográfica hacia el este formando un frente arquitectónico flanqueado 
por danzas de tres arcos escarzanos con vista hacia los cerros. Lamentablemente, esta no pudo ser concluida; sin embargo, es imprescindible reconocer el potencial de las calles de la ciudad como un sistema armonioso de desplazamiento, lo que Rodríguez Camilloni ha puntualizado con acierto al descubrir la originalidad de dicha concepción urbanística la misma que quedó reflejada en su recorrido imaginario:

Se imaginó partiendo del Palacio de los Virreyes en el extremo norte de la plaza Mayor, con un séquito de coches y calesas tomando la calle Fierro Viejo a mano izquierda que desembocaba en la plazuela de la iglesia de los Desamparados y atravesando el arco del Puente, que a la vez marcaba el ingreso a la ciudad. Este daba acceso al Puente de Piedra (hoy puente Trujillo), que cruzando el río Rímac comunicaba con la recta que terminaba en la iglesia de San Lázaro. En la intersección con la plazuela de esta iglesia, se hubiera topado con la recta de las calles del actual jirón Chiclayo, pasando enfrente de la iglesia de Nuestra Señora de Copacabana y desembocando a la Alameda de los Descalzos recorriendo su perímetro en sentido horario, recorrido que le hubiera permitido tener a la vista a las tres iglesias, que definirían el espacio de la alameda. Santa Liberata, la iglesia de los Descalzos y la del Patrocinio; llegando al extremo sur de la alameda hubiera girado a la izquierda hacia la Navona de Lima siguiendo el recorrido hasta el fondo pasando por la fuente escenográfica y hubiese continuado con dirección sur este por el actual jirón Hualgayoc hasta la Plaza de Toros, obra de Amat y completar el circuito a través de la Alameda Nueva bordeando la ribera del río hasta el acceso del Puente de Piedra y retornar así a la plaza Mayor. Espectacular recorrido formando un todo urbano, natural, en una palabra, barroco.

\section{Sentido procesional de las vías}

En Lima, si bien las calles comunicaban a las iglesias y se unificaban al final en el momento del desplazamiento de las procesiones, era evidente un solo propósito: resaltar el urbanismo barroco en la Calle de la Amargura.

\section{Remates visuales}

En este aspecto, se puede distinguir en Lima virreinal remates visuales de tres tipos:

\footnotetext{
Remate visual a una iglesia en posición axial desde la calle que le antecede en línea recta. Es el caso de la calle de la Amargura que remata en la plazuela e iglesia de la Recoleta o Recolección Dominica de Santa María Magdalena y el de la calle Trujillo que remata en la iglesia de San Lázaro. Este último ejemplo proviene del siglo XVI, denominado por Mattos-Cárdenas como Modelo Jerarquizado.
}

Remate visual con factor sorpresa cuando la vía se abre a un espacio monumental que se viene atisbando en el camino como el caso del Conjunto de San Francisco.

- Remate visual desde una alameda, como el caso de la Alameda de los Descalzos, que conduce a la Recolección Franciscana Santa María de Los Ángeles y a la Alameda de Guía que remataba en la Recolección Agustina Nuestra Señora de Guía, ambas ubicadas en los extramuros de la ciudad, en la otra banda del río Rímac y alejadas del núcleo central del barrio de San Lázaro.

- Otros remates visuales como el caso de la parroquia de Santa Ana y los monasterios de Santa Catalina y de Santa Clara. No se mencionan los remates producidos por las manzanas dobles por no existir elementos arquitectónicos que resalten dicho remate.

\section{Categorización vial toponímica, funcional y simbólica}

Nuevamente recurrimos al caso de la Calle de la Amargura, única calle con una extensión de nueve cuadras y una denominación que fue recurrente en Hispanoamérica. Se conoce de otros casos extraídos del Padrón de los indios de Lima en 1613, recopilado por Juan Bromley, sobre el que basó la reconstrucción del Plano de Lima en el año 1613 donde se identifican cinco nombres de calles que abarcaban de tres a cuatro cuadras y que se enumeran a continuación:

Calle del Cercado, que se extendía desde la puerta principal del pueblo del Cercado de Indios hasta la Plaza de Santa Ana. Comprendía a su vez tres calles, denominadas: calle 1era. del Cercado, calle 2da. del Cercado y calle 3era. del Cercado.

Calle de las Descalzas que se extendía desde el monasterio de las Descalzas hasta la Plaza de la Inquisición. Comprendía a su vez tres calles denominadas: calle 1era. de las Descalzas, calle 2da. de las Descalzas y calle 3era. de las Descalzas.

- Calle de Santa Clara, desde el colegio Real hasta la plazuela de Santa Clara. Comprendía a su vez cuatro calles denominadas: calle 1era. de Santa Clara, calle 2da. de Santa Clara, calle 3era. de Santa Clara y calle 4ta. de Santa Clara.

- Calle de San Andrés, desde la altura del monasterio de la Concepción hasta la plaza de Santa Ana que comprendía tres calles denominadas: calle 1era. de San Andrés, calle 2da. de San Andrés y calle 3era. de San Andrés.

Calle de San Agustín, que se extendía desde el Convento de San Agustín hasta la parroquia de San Sebastián, 
comprendía cuatro cuadras: 1era. cuadra de San Agustín, 2da. cuadra de San Agustín, 3era. Cuadra de San Agustín y 4ta. cuadra de San Agustín

Calle de Santo Domingo, que se extendía desde el convento de Santo Domingo hasta la altura donde años más tarde se levantó la iglesia de Santa Rosa de los Padres y comprendía tres cuadras: 1era. cuadra de Santo Domingo, 2da. cuadra de Santo Domingo, 3era. cuadra de Santo Domingo.

Cabe destacar que todas estas calles iban de este a oeste o viceversa, ninguna de norte a sur. Si para el año 1613 no se mencionó la Calle de la Amargura, es porque aún no se había originado la procesión que le dio nombre a la calle y apenas dos años antes, en 1611, se había establecido definitivamente la Recolección de Santa María Magdalena.

\section{Alamedas y paseos}

En Lima del siglo XVII, se da el caso de la apertura de dos alamedas, alejadas del bullicio de la ciudad, que conducían a las Recolecciones de los Franciscanos y de los Agustinos, en la otra banda del río Rímac. El camino sobre el que se construyó la Alameda de los Descalzos fue abierto en 1603, como se encuentra documentado en el Libro de Cabildos: "Se propuso enderezar las cuadras desta ciudad y el camino de San Lazaro que a de yr a dar al monasterio de los descalzos[...]"; asimismo, el Cabildo dispuso en 1609 hacer una alameda en el Camino de los Descalzos:

[...]se propuso como el marques de montesclaros visorrey les habia tratado y dicho que seria bien se hiciese una alameda desde el molino de francisco de san pedro hasta en conbento de los frayles descalzos para que el camino se aderece y limpie de las muchas piedras y arena que en el ay para que con mayor facilidad la gente devota de aquella religión frecuente el ir alla y los rreligiosos benir a esta ciudad que por ello y no aber ningun alibio de sombra en tiempo de berano no lo pueden hacer ... y que su señoria ayudaria con alguna cantidad de pesos para que tenga efecto/ $\mathrm{Se}$ acordo y determino se haga la dicha alameda en el sitio y parte donde se a rreferido haciendose las fuentes en ella que sean necesarias $[\ldots]$

Finalmente, la Alameda de los Descalzos fue inaugurada en 1610 .

El camino que conducía a la Recolección Agustina Nuestra Señora de Guía está registrado en el plano delineado por Bernardo Clemente Príncipe, fechado en el año 1674, camino flanqueado por árboles como el de la Alameda de los Descalzos. Este camino fue conocido como "calzada de Guía” o "alameda de
Guía”. La Recolección se estableció definitivamente con su tercera iglesia en aquel lugar tan alejado del centro de la ciudad, en el año 1636. Su iglesia "perfectamente acabada” se estrenó en 1644.

\section{Diferenciación urbana horizontal}

El establecimiento del pueblo de indios del Cercado queda situado a competente distancia de la ciudad. Para Torres Saldamando la ciudad terminaba al fundarse aquel y transcribe la mensura practicada en el año 1593 a solicitud del Procurador de la Compañía de Jesús a cuyo cargo se encontraba el pueblo

[...] que en cumplimiento de lo proveído por el dicho Alcalde han medido las cuadras que hay desde la iglesia mayor desta ciudad hasta el Cercado de los Indios que es el pueblo de Santiago y que desde la dicha iglesia mayor hasta la iglesia de Santa Ana que es el hospital de los indios estan las calles por sus cuadras y hay siete cuadras y cada cuadra tiene ciento y cuarenta y cuatro varas de medir de la medida general de Castilla y de este reino que es toda una u que desde la dicha iglesia de Santa Ana hasta el dicho Cercado y pueblo de Santiago no esta por cuadras sino que va una calle derecha y la midieron con la dicha vara por las paredes y hay 974 varas que reducidas a cuadras son otras siete cuadras menos 6 varas por manera que desde la dicha iglesia mayor hasta el dicho pueblo de Santiago y Cercado de Indios hay catorce cuadras menos seis varas y las cuadras que dividen las calles miden doce varas cada una lo cual asi midieron como dicho tienen y que desde la iglesia de Santa Ana hasta el Cercado hay solamente dos calles [...]

Así, el pueblo queda diferenciado de la ciudad no solo por la distancia, sino por la orientación.

\section{Diferenciación urbana vertical}

Lima era una ciudad horizontal donde predominaba un solo piso de altura; sin embargo, la construcción de un conjunto de torres, bóvedas y medias naranjas produjo una marcada diferenciación vertical que caracterizó la ciudad conventual y barroca.

La solitaria torre de Santo Domingo destacaba de manera singular en el conjunto señalado.

\section{Lo aparente sobre lo real}

La construcción de la muralla de Lima si bien es el resultado de una larga discusión entre las autoridades civiles y eclesiásticas, fue levantada con adobes lo que creó la imagen de una plaza fuerte. Se dio inicio a su construcción en el año 1684 y se terminó en 1687. El plano de Lima de 1685 del mercedario Pedro Nolasco (figura 1), incluye las murallas aun cuando 
se encontraba en pleno proceso de construcción. Es una muestra más del sentido barroco de su representación. Es más, para afianzar la defensa cerrada en el dibujo, deliberadamente fueron omitidos los arrabales de la ciudad.

Glave destaca la asociación de la "Estrella de Lima" con la forma que adquirió la ciudad cuando fue amurallada; Echave y Assu empleó en su crónica La estrella de Lima convertida en sol sobre sus tres coronas, publicada en Amberes en 1688.

\section{La formación de plazuelas conventuales}

El padre San Cristóbal estudia el proceso histórico de apertura de las plazuelas en Lima virreinal y señala que: "La existencia de plazuelas en el plano de Lima constituye un fenómeno urbanista innegable, cualquiera que pudiera ser su autenticidad como barroco".

En efecto, si bien Mattos-Cárdenas no incluye entre las reformas urbanas de los siglos XVII y XVIII a la apertura de plazuelas conventuales limeñas, estas constituyen una modificación urbana característica de la ciudad de Lima virreinal.

Las plazuelas conventuales son los espacios ubicados frente a los conventos e iglesias que fueron abiertos en el periodo virreinal rompiendo el esquema rígido del damero. Este fenómeno urbanista propio de Lima lo recogemos para incluirlo como una de las características del barroco urbano limeño, creadas para la convivencia ciudadana secular los días domingos y fiestas de guardar. El proceso de apertura de las plazuelas conventuales limeñas no afectó la traza del damero. Consistió en el recorte de parte del solar con frente a la iglesia para ser transformado en un espacio libre y de carácter público. Algunas de ellas pueden apreciarse en la figura 2 (plano de Lima en el siglo XVIII obtenida en la web).

Un caso particular lo constituye la plazuela del Conjunto Monumental conformada por la iglesia y convento de San Francisco, la capilla de la Cofradía de Nuestra Señora de la Soledad y la capilla del Milagro. Esta plazuela fue la primera que existió en Lima.

El proceso histórico de apertura de las plazuelas limeñas analizado por el padre San Cristóbal nos lleva a reflexionar y establecer las épocas en que estas fueron formadas. Es así que a través de los diferentes planos antiguos de Lima podemos dar cuenta del proceso histórico de las plazuelas conventuales y de su disposición, por lo general al frente de las iglesias conventuales o unidas a los atrios, como la de San Francisco.

Claramente, se puede apreciar en el plano de Lima de 1685 de Pedro Nolasco, de gran valor testimonial, la formación de la plazuela de La Merced y la plazuela de San Pedro (Compañía de Jesús). Está documentado que según acta del Cabildo de Lima, en 1626 el Procurador General de la Compañía de Jesús Fray Cristóbal Garcés se presentó al Ayuntamiento diciendo que se llegó a un trato con el vecino Juan Esteban de Montiel para que le vendiese las casas que tenía frente a la Iglesia de la Compañía para formar una plaza pública para ornato del pueblo. Que en esa plaza que estaría frente a la nueva iglesia en aquel entonces en construcción realizarían los padres predicaciones del Evangelio y adoctrinarían a los niños indios y negros; la plazuela serviría además para que en ella estuvieran los caballos y carrozas y los negros y criados de las personas que concurrían al templo.

Según criterio establecido por el padre San Cristóbal, la Plazuela de La Merced pudo haber sido abierta en la década de 1620 a 1630 coincidiendo con la etapa de remodelación de la planta de la iglesia. Por tanto, ambas plazuelas, la de la Compañía y la de los mercedarios, serian de la misma época.

En cambio, no son muy claros los orígenes de la formación de las plazuelas de Santo Domingo y de San Agustín. Por un lado, el padre San Cristóbal las clasifica en el grupo de plazuelas formadas en el siglo XVIII. A la plazuela de San Agustín la considera como anterior a 1746, al hacer referencia a las gestiones emprendidas por los agustinos para comprar los solares frente a la iglesia y abrir en ellos una plazuela hacia 1720. En cambio, Bromley asocia la formación de la plazuela a cuando se levantó en 1612 el corral de comedias.

La formación de la plazuela de Santo Domingo es más tardía según el padre San Cristóbal. Sin embargo, Bromley cita que en el año de 1563 en el Cabildo

Figura 1. El plano de Lima de 1685 del mercedario Pedro
Nolasco Plano de Lima.
Gunther, Juan (1983).

Fuente. Juan Gunther. (1983).Colección de planos de Lima. 

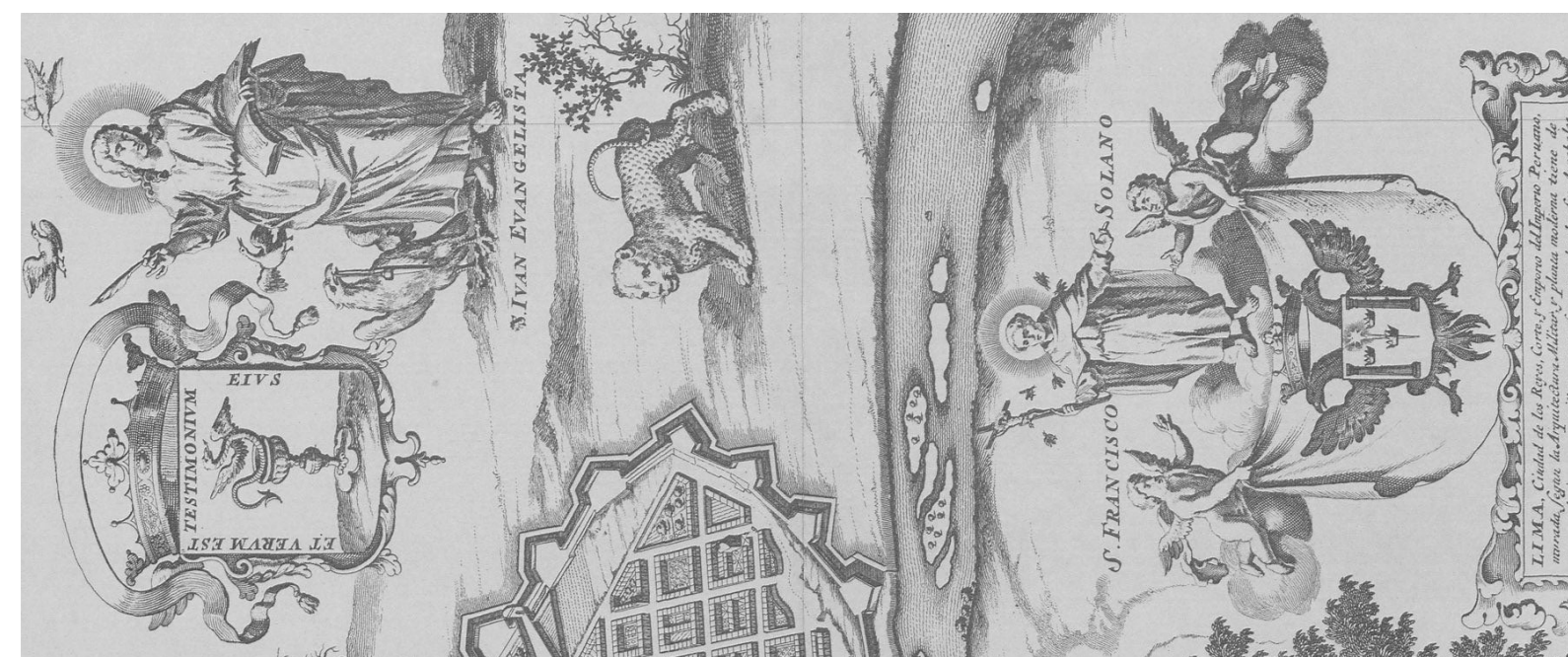

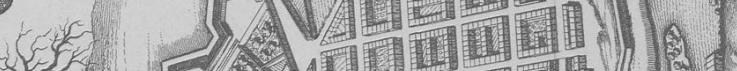
Y 15 ,

OS 5 .

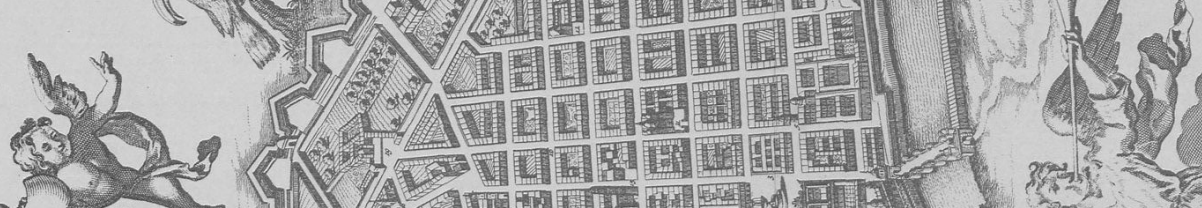

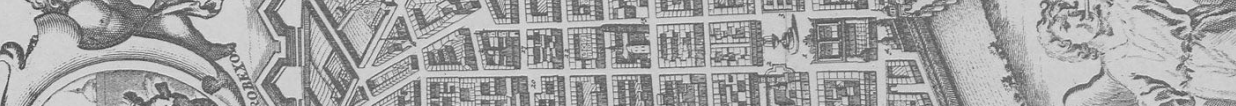

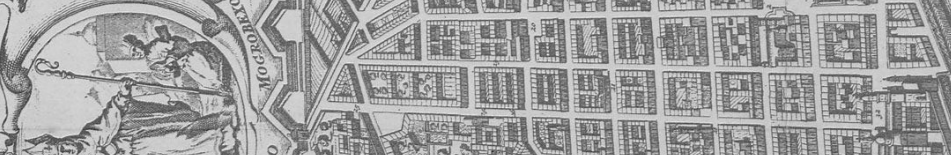

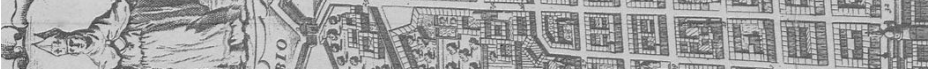
1. -7 .

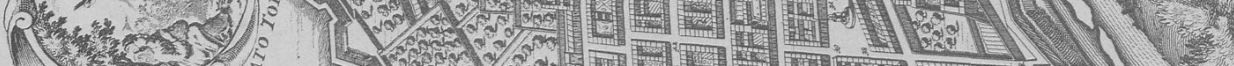
[L C.

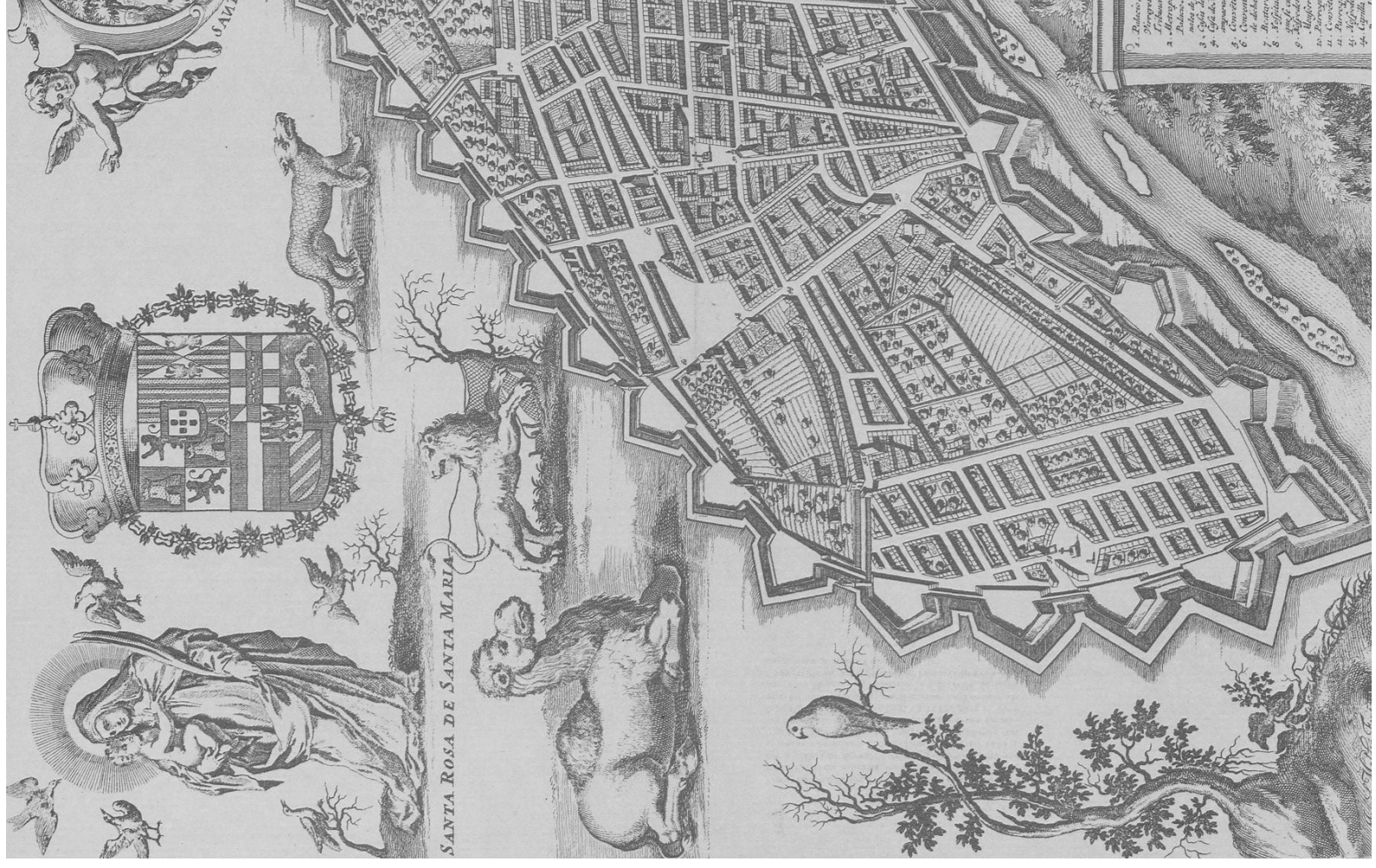




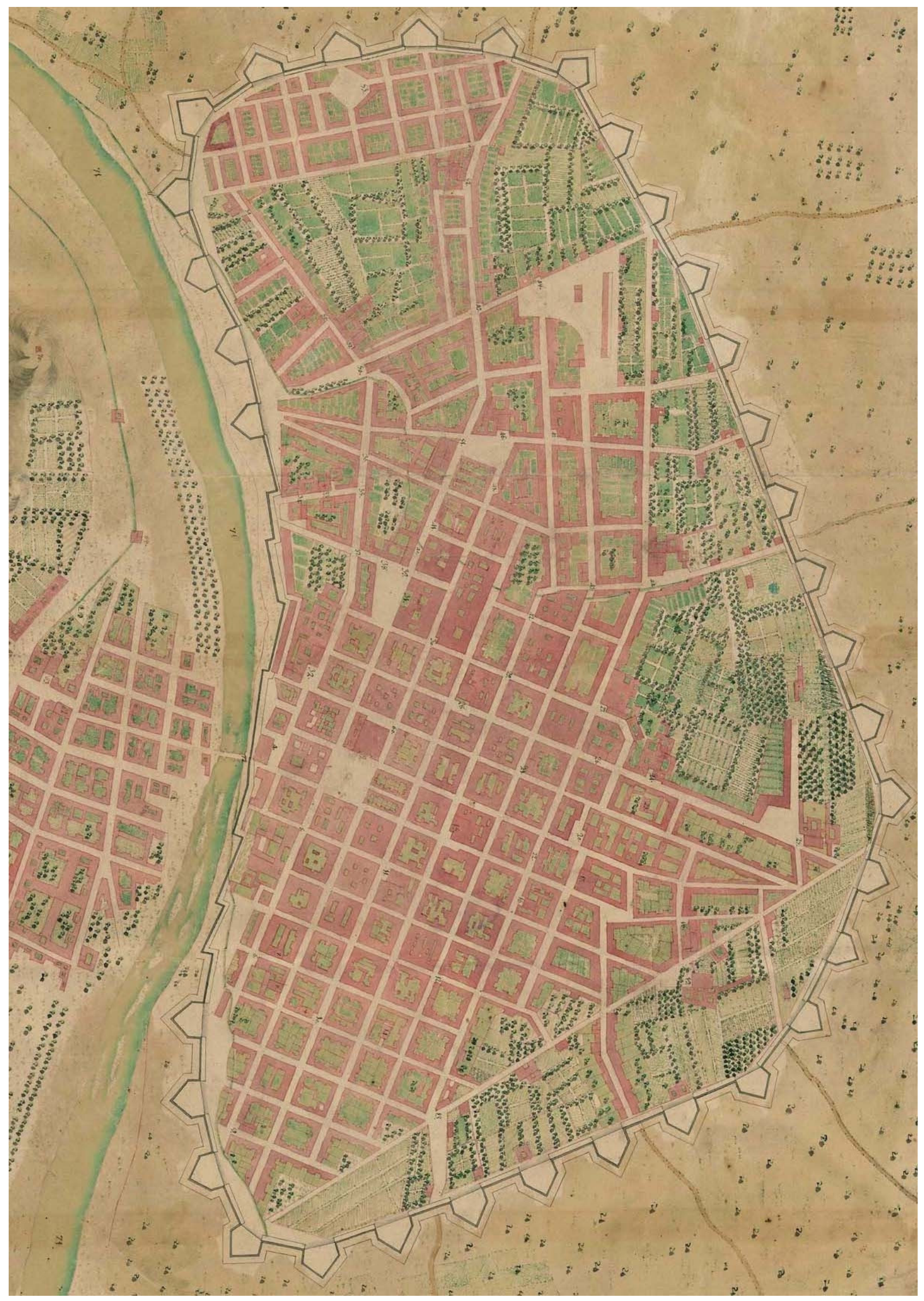


de Lima los frailes de Santo Domingo reclamaban que la plazuela de María de Escobar les pertenecía y que se debiera conservar para ornato de la población; años después, por Real Audiencia, en 1576, ya se hallaba la plazuela en posesión del Convento de Santo Domingo. Ningún plano de Lima del siglo XVII registra estas plazuelas conventuales del lado occidental de la ciudad. El plano de la ciudad de Lima y puerto del Callao de 1768 aun no siendo exacto por las deficiencias en la representación de la muralla de Lima, sí grafica las plazuelas de Santo Domingo y de San Agustín, así como el resto de plazuelas abiertas hasta dicho año.

Para efectos de demostrar el proceso histórico de la apertura de las plazuelas conventuales durante el Barroco, se consideran suficiente los ejemplos señalados. Se subraya el caso específico de la plazuela de San Francisco que tiene la particularidad de ser adyacente al atrio de la Iglesia; es decir, sin haber calle de por medio que la separe. Se destaca este ejemplo único por ser un testimonio magnifico que caracteriza el urbanismo barroco limeño: "[...] el de extender más la plazuela y descubrir mejor la fachada de la iglesia[...]". En efecto, es poco difundida la transacción efectuada entre la Cofradía de Nuestra Señora de la Soledad y el Convento de San Francisco en 1669 cuando aún ocupaba la primitiva Capilla de la Soledad parte de la plazuela, como la observamos en la figura 3 (detalle de pintura anónima del siglo XVII proporcionada por la Cofradía de Nuestra Señora de la Soledad). La argumentación acerca de derribar dicha capilla y construir una nueva se aprecia en el siguiente extracto del concierto notarial:

[...] se hiciese mas capaz así en lo ancho y largo como en lo alto por haber crecido esta ciudad y desde que se fundo dicha capilla en mas de otro tanto que estaba cuando se fundo y haber crecido por lo mismo el numero de sus vecinos y habitantes como también la devoción de los fieles a la santa imagen de Nuestra Señora de La Soledad y el ornato y lustre de su capilla siendo como ya es de ordinario su procesión los viernes santos la mas lucida y autorizada que se hace en esta ciudad y sus fiestas que en el discurso del año

Figura 2. Plano de Lima en el siglo XVIII.

Fuente. Lima y el Callao: guía de arquitectura y paisaje. Universidad Ricardo Palma. 2009. se celebran tan graves y de tanto lucimiento que por el gran concurso de gente que concurre a ella no caben en dicha capilla[...] (SAN CRISTOBAL, A. (1993). La construcción de la Iglesia de la Soledad. Historia y Cultura № 22.)

Es importante insistir que las iglesias de Lima se edificaron desde sus inicios sin plazuelas conventuales. Estas aparecieron primordialmente como espacios creados para la convivencia ciudadana promovidos por los conventos de cuya iglesia estaban al frente.

La formación de los atrios en las manzanas conventuales formando escuadra entre la portada de la iglesia y la portada del templo es otra característica del urbanismo limeño, sin decir que sea propiamente del barroco, pero que en su tiempo rompió la rigidez de la continuidad de los paramentos que delimitaban las calles de la ciudad.

En este aspecto, tenemos que señalar que no en todos los casos se dio la escuadra perfecta como el caso del atrio de la Compañía o de San Agustín. Se tienen los atrios a doble escuadra como las de los conventos de San Francisco y Santo Domingo dada la complejidad de su conformación volumétrica que en el caso de San Francisco da cabida a dos capillas y en el caso de Santo Domingo, a la capilla de la Veracruz y la prolongación del coro alto sobre la entrada de los pies de la iglesia.

\section{La Calle de la Amargura}

De todas las calles de Lima virreinal, destaca aquella cuyo trazo recto fue interrumpido por el emplazamiento de la Recolección Santa María Magdalena de la Orden de Santo Domingo, al sur de la ciudad, que daba su iglesia frente a la Calle de La Amargura desde que se creó la procesión que le dio ese nombre, en el primer tercio del siglo XVII.

Las autoridades civiles tenían previsto continuar la calle recta, según estaba proyectado, aun cuando antes del establecimiento de la recolección dominica esta calle llegaba hasta el antiguo camino inca que conducía a Pachacamac.

Hacia el año 1613, según el Padrón de Indios, el tramo de calle que tenía como fondo a la recolección dominica fue llamada calle de la Recoleta Dominicana. Bromley relata que para aquel año en dicha calle vivían renombradas personalidades entre profesionales y regidores. Lo importante es que dicha cuadra ya estaba poblada por aquel entonces o habría recién empezado a poblarse desde que se estableció la reco- 


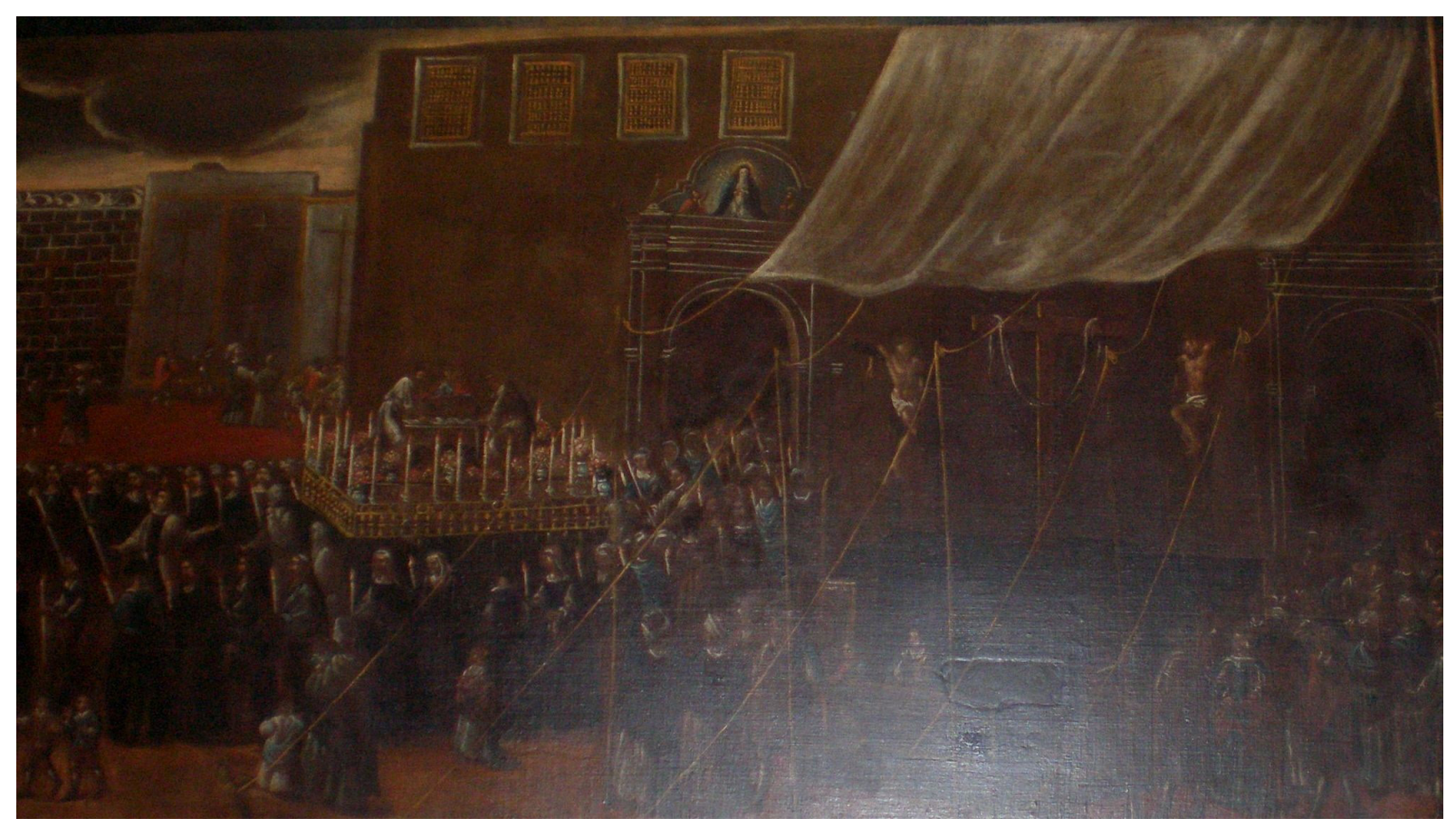

Figura 3. Detalle de pintura anónima del siglo XVII.

Fuente. Archivo de la Cofradía de Nuestra Señora de la Soledad lección dominica; no hay noticias de las dos cuadras anteriores (actuales cuadras 7 y 8 del jirón Camaná), lo que nos hace suponer que antes de la fundación de la recoleta, la que después se llamaría Calle de la Amargura llegaba hasta su sexta cuadra.

En cuanto al trazado, si bien estaba impuesto continuar la rectitud de las calles, esta no pudo darse de esta manera en este sector sur de la ciudad por encontrarse con la preexistencia de dos caminos. nos hemos referido ya al camino de los Llanos o camino a Pachacamac; viniendo de norte a sur por la calle que analizamos se encontraba primero con otro camino en dirección este-oeste, el cual fue respetado y es el que ha llegado a nuestros días con el nombre de jirón Quilca. Tanto la orientación de dicho camino como su trazado impidieron conformar con el cruce de la Calle de la Amargura cuatro manzanas regulares. Lo que quedó fueron cuatro manzanas no solo irregulares, sino de diferente forma entre sí, hasta el término de la ciudad que años más tarde fue cercada por la muralla.

Esta encrucijada de calles conformó una de las cuadras más extensas de la ciudad. Para el estudio de esta calle estamos partiendo de su momento de mayor auge, para retroceder en el tiempo y conocer sus orígenes. 
José Gálvez seleccionó para armar su almanaque callejero las doce calles que más se relacionaban con cada mes del año, y no pudo elegir mejor exponente que la Calle de la Amargura para identificar el mes de abril asociado a la Cuaresma de Lima. "Desde muy al comienzo del siglo XVII llamábase así y aun hasta avanzado el XIX en muchas citas, pues la Amargura de hoy no es sino remanente del nombre del jirón entero, Camaná en nuestros días”.

Es el caso de la Calle de la Amargura, en particular, un singular ejemplo de aplicación de la microhistoria de la ciudad que enfatiza la piedad limeña porque sintetizaba en una vía lo que manifestaba la ciudad barroca del seiscientos plasmada en su traza tanto en edificios, vivencias, personajes y, particularmente, en sus procesiones y, para ser más específicos, en la procesión de la Amargura.

Esta calle limeña ha pasado desapercibida en nuestro tiempo por la ruptura de la relación primigenia entre los conventos que interconectaba que eran de la misma orden. Era frecuentada en tiempo de recreaciones o simplemente por ser ruta obligada de sus santos moradores, pero el hecho que más da significación a esta vía es la procesión que le dio nombre.

Para el año 1636, existe la referencia del protocolo del concierto de obra de Joseph de la Sida para la torre de la iglesia del convento de San Agustín: "Item he de derribar el campanario que hoy esta hecho y todas las paredes de adobe sobre que carga y la pared que mira a la calle de la Amargura hasta llegar al suelo hollado que esta sobre la capilla de San Miguel[...]"

La Calle de la Amargura fue testigo de la presencia de Fray Martín de Porras. De la letra del cronista Juan Meléndez se sabe por ejemplo que, refiriéndose a Martín, escribió: "Otra vez en la calle, que llaman de la Amargura, vio a otro perrillo, no muerto, pero cubierto de piedras, y al parecer necesitado de sustento. Lastimose del miserable, Fray Martín, y volviendo al Convento de la Magdalena, de donde venía, buscó sustento para el bruto, y dándoselo, prosiguió su camino." Una vez más, para 1681, se hablaba de "la calle que llaman de la Amargura”.

\subsection{La Amargura en otras ciudades hispanoameri- canas}

No solo Lima contó con una vía sacra que rememoraba el paso de Jesucristo con la Cruz a cuestas por la Calle de la Amargura. Fue un hallazgo encontrar que otras ciudades hispanoamericanas conformaban una calle con la misma denominación.

En la ciudad de Santiago de Cuba, la Calle de la Amargura se inicia en una de las esquinas de la catedral y continua hacia el oeste en dirección al sitio que en el siglo XVII ocupó la ermita de Santa Ana.

Así también se puede nombrar la Calle de la Amargura de Santa Fe de Antioquia en Colombia y la de Santiago de Querétaro en México.

En Camaguey, la Calle de la Amargura alcanzó una extensión de 1575 metros; partía del convento de San Francisco y finalizaba junto a la ermita de Santa Ana. En Bayano, la calle llamada de la Cruz Verde recorría la ciudad desde la fachada de la iglesia parroquial hasta el extremo sur, pasando por el convento de San Francisco, por la Iglesia de la Luz y cortando una calle transversal nombrada de la Amargura que se dirigía a la ermita de San Blas.

En la villa de San Juan de los Remedios, la mencionada calle atravesaba la ciudad, desde la Plaza Mayor hasta los alrededores de la ermita del Santo Cristo en el límite oeste y en la villa de Guanabacoa, arrancaba desde el sitio de la primera plaza de la iglesia parroquial, hoy ocupado por el convento de Santo Domingo, en dirección hacia el oeste.

En Trinidad, el calvario ocupó una posición natural en la bajada hacia el río. La calle de la Amargura o de las Cruces, extendida por el norte del cuerpo urbano, remataba en este lugar. En la villa Sancti Spiritus, la calle describía una trayectoria alargada e irregular desde las cercanías de la iglesia mayor hasta cruzar el río por el Paso Real, después de pasar por la plazuela y ermita de Jesús Nazareno.

\subsection{El sistema conventual de la Calle de la Amar- gura}

En el trayecto de las nueve cuadras que compone la antigua Calle de la Amargura, se localizan dos de los conventos grandes fundados en el ciudad de Lima: El Convento Grande de Nuestra Señora del Rosario, de la Orden de Santo Domingo, y el Convento Grande de Nuestra Señora de Gracia, de la Orden de San Agustín, con tan solo dos cuadras de distancia entre sí; el beaterio de Jesús María convertido años después en el Convento de Jesús María de religiosas capuchinas y como remate de la calle se encontraba la Recolección de Santa María Magdalena. 


\section{El Convento Grande del Rosario}

Fueron los dominicos y mercedarios los que tuvieron el privilegio de obtener los solares ubicados en calles que desembocaban directamente a la Plaza Mayor, el primero a escasamente una cuadra de distancia. Sin embargo, David Rohr documenta que la ocupación inicial de los dominicos fue en un local ubicado en la calle a espaldas de la catedral, según descripción de Pedro Girón. Asimismo, desde tiempos tempranos se produjo la primera modificación al trazado de la ciudad al adquirir los dominicos dos solares adicionales que fueron añadidos al terreno original, absorbiendo la llamada calle Tigre que había conectado en un inicio lo que hoy conocemos como jirón Cailloma que venía desde la orilla del río, formando una manzana casi doble.

\section{El Convento Grande de San Agustín}

El caso del emplazamiento del convento de San Agustín es muy distinto, pues a su llegada en 1553 se le asignó un terreno muy alejado de la plaza mayor, el que ocupó después la parroquia de San Marcelo. Con la oposición de dominicos y mercedarios, los agustinos ocuparon en 1571 el solar ubicado en la recta de Santo Domingo; colocaron la primera piedra de su iglesia en 1574.

\section{El Beaterio y Convento de Jesús María}

Hacia el año 1673, Nicolás Ayllón fundó en su vivienda la Casa de Jesús María, que era un recogimiento de doncellas. Esta casa había pertenecido a don Miguel de Alloza y Olivan y contaba con huerta y oratorio. Luego de su muerte, acaecida en el año 1677, el oratorio fue ampliado a capilla sobre la casa vecina que pertenecía a don Francisco de Mendoza y Cisneros y se convirtió en beaterio. Años más tarde, en 1698, María Jacinta de la Santísima Trinidad que es el nombre que adoptó la viuda de Ayllón consiguió la licencia para fundar un convento de religiosas capuchinas. Para el año 1722, se encontraba estrenada la nueva iglesia, que se consiguió a través de la limosnas recolectadas, que se emplazó formando esquina con la Calle de la Amargura. Puede confirmarse la posición de la Casa y Beaterio de Jesús María en el plano de Nolasco, que aparece en el trayecto de la calle transversal a la de Amargura cuando se llamaba Capuchinas y más tarde Calle de Jesús María.

\section{La Recolección de Santa María Magdalena}

El fundador y promotor de la Recolección Dominica Santa María Magdalena fue Fray Juan de Lorenzana quien deseoso de fundar un convento para guardar con rigor las reglas de la Orden logró obtener la licencia del virrey Gaspar de Zúñiga y Acevedo el 19 de enero de 1606 y posteriormente la del arzobispo Toribio de Mogrovejo el 11 de marzo de ese mismo año. La advocación de la recolección se adoptó el 23 de junio de 1606 con el nombre de Santa María Magdalena, cuya imagen fue llevada en procesión.

El lugar inicial elegido "[...] ni dentro, ni lexos de la Ciudad [...]" (Meléndez) se trabajó de modo que el convento tuviera las puertas en la ciudad y el claustro y las celdas, en el campo, dentro de una buena cerca. Era la huerta conocida con el nombre de San Jacinto; habían unas casas huertas que lindaban de una parte con la huerta de Juan Días y por otra con las tierra de Francisco Mansilla Marroquín y una huaca de piedra que estaba por estas tierras que iban al Callao; por la espalda lindaba con los alfalfares de dicha casa huerta, según Acta de Fundación de la Recolección. Permanecieron pocos años allí toda vez que en 1608 los religiosos solicitaron al Cabildo el respectivo permiso para edificar su iglesia en el lugar que describe el cronista Cobo consignando el año de fundación 1611:

[...] esta en el fin de la ciudad y de la calle traviesa que comienza en la orilla del Río y convento de Nuestra Señora del Rosario de la misma orden, de manera que estos dos conventos cogen los extremos de las dichas calles y lados de la ciudad norte-sur, y desde el uno se divisa el otro, con haber distancia de diez cuadras de por medio[...] (Cobo, 1878).

\subsection{El proceso histórico de la apertura de plazuelas conventuales en la Calle de la Amargura}

De la información cartográfica disponible, se concluye que en el siglo XVII a lo largo de la Calle de la Amargura no se dieron visos de apertura de plazuelas enfrente de las iglesias, como sí los hubo en la de los jesuitas y de los mercedarios. En efecto, recién es posible observar con claridad la formación de las plazuelas conventuales de Santo Domingo y San Agustín en el plano de Lima y puerto del Callao del año 1768 que obra en la Biblioteca Nacional de España, y que a pesar de que varios de sus elementos no están en proporción (por lo que resulta solo referencial), ilustra el desarrollo de las plazuelas conventuales y si bien no grafica los atrios, representa la ubicación de los conventos e iglesias a lo largo de la calle. 
Figura 4. Iglesia de Jesús María y José - siglo XIX. Fuente. Leonce Angrand. (1972).

Así como ha sido señalado, se tienen noticias de la apertura de las plazuelas de los conventos mayores concentrados en esta parte de la ciudad antes del terremoto de 1746, probablemente contemporáneos a la formación del atrio lateral de la iglesia de Jesús María que en el primer tercio del siglo XVII alcanzó a ampliarse hasta la Calle de la Amargura de manera que su atrio lateral se formó paralelo a dicha calle.

En el siglo XVII, lo que destaca es la amplia plazuela irregular adosada al atrio de la iglesia de la recolección Santa María Magdalena que no hace más que enfatizar el remate de la Calle de la Amargura en simetría axial entre la calle y la fachada de la iglesia. El trazo irregular de la plazuela se alza en yuxtaposición con el camino inca preexistente dado a conocer por el arquitecto Mattos-Cárdenas.

\subsection{Remate visual, posición axial y calle recta}

La Calle de la Amargura ilustra como ninguna otra calle de Lima virreinal las tres pautas que caracterizan el barroco limeño: el remate visual, la posición axial y la calle recta que le da el sentido procesional a la vía; se puede agregar la pauta que otorga la conexión espacial entre dos hitos en los extremos de la calle Amargura: la torre de Santo Domingo y la Iglesia de la Recolección Santa María Magdalena como fondo de perspectiva.

En el siglo XVII, contamos con el plano del mercedario Pedro Nolasco de 1685 para documentar fehacientemente la disposición de la calle. Solo del siglo XIX, se pueden obtener evidencias panorámicas de esta calle, de la mano de Leonce Angrand, como es aquel apunte en el que esboza a la iglesia de Jesús Ma-

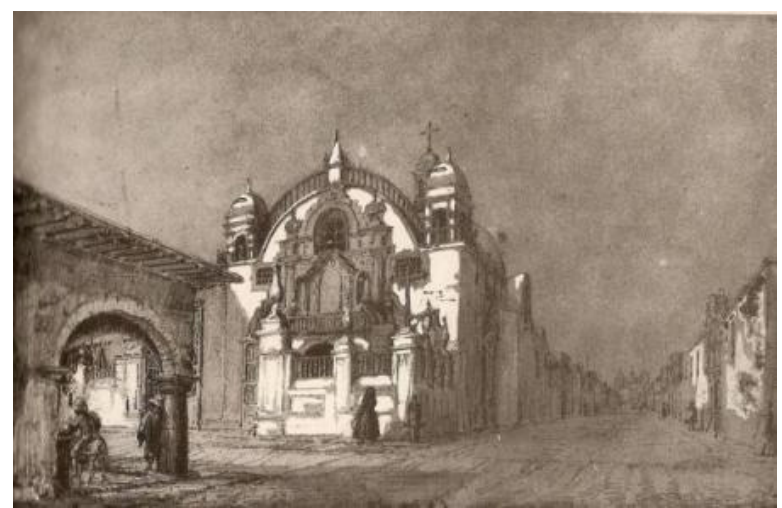

ría. Se aprecia en el fondo de perspectiva a la Recoleta (figura 4); así también, un apunte de la Recoleta Dominica aproximándonos a la realidad del ambiente de la época, de características semirurales, como lo señaló Meléndez, con la puerta en la ciudad y las celdas en el campo (figura 5).

Concluimos la existencia de un urbanismo barroco en Lima de manera conjunta con las otras manifestaciones de la cultura barroca que se desplegó por toda la ciudad. En términos urbanísticos, existieron evidencias propias del barroco como el arco del puente, la Portada de Guía, las alamedas que ambientaron el trayecto de las recolecciones ubicadas en los extramuros de la ciudad, los remates visuales y más tardíamente la Navona de Lima. Puede afirmarse que el urbanismo limeño es indisoluble a los usos que dieron vida a la ciudad. La Calle de la Amargura es expresión del urbanismo barroco que se manifiesta a través del remate visual, la posición axial y la calle recta integrada al sistema de apertura de plazuelas conventuales a lo largo de su trayecto. Constituye, entonces, un espacio urbano de vocación religiosa único en su tipo en la Lima virreinal. Deseamos que este conocimiento conlleve a la recuperación del valor histórico y urbanístico de la calle y principalmente de su trazado. En efecto, la recuperación de la sección original de la vía en el tramo afectado por el ensanche (cuadras 6, 7 y parte de la 8 del jirón Camaná) estuvo previsto por las autoridades locales hace algunas décadas atrás; sin embargo, a la fecha es una tarea pendiente. Esperamos que el presente artículo y los estudios venideros sirvan de motivación y sea un aporte para la recuperación de la Calle de la Amargura. 


\section{Bibliografía}

Acosta, R. (1997). Fiestas Coloniales Urbanas. Lima: Otorongo Producciones.

Álvarez, L. (1996). La fiesta religiosa barroca y la ciudad mental. Recuperado el 27 de octubre de 2008 de http:// www.dipalme.org/Servicios/Anexos/anexosiea.nsf/ VAnexos/IEA-a1rp_c1/\$File/a1rp_c1.pdf.

Aziani, A.; Benito, J.; Battista, G.; Paccosi, G.; Pini, F. \& Villacorta, L. (2006). Toribio Alfonso de Mogrovejo (1538-1606) Identidad y Multiculturalidad en América Latina. Textos de la exposición realizada con ocasión del cuarto centenario de la muerte de Toribio de Mogrovejo, Lima (Perú)- Rimini (Italia) 2006.

Barbagelata, J. \&. Bromley, J. (1945). Evolución Urbana de Lima. Lima: Lumen.

Bernales, J. (1972). Lima, la ciudad y sus monumentos. Sevi1la: Escuela de Estudios Hispanoamericanos.

Benito, J. (2010). El Señor de los Milagros, rostro de un pueblo. El protagonismo de la Hermandad de las Nazarenas. Lima: Universidad Católica Sedes Sapientiae.

Bisbal, R. \& Ríos, M. (1989). Reconstrucción Historiográfica de la Recolección Agustina Nuestra Señora de Guía
- Siglo XVII - Lima - Perú- Valoración urbano - arquitectónica contemporánea. (Tesis de pregrado no publicada). Facultad de Arquitectura, Universidad Ricardo Palma, Lima.

Bromley, J. (2005). Antiguas Calles de Lima. Lima: Municipalidad Metropolitana de Lima.

Busto, J. (2006). San Martín de Porres. Lima: Fondo Ed. PUCP.

Campos, J. (2001). Exequias en Honor de Felipe III celebradas en Lima en 1621. Hispania Sacra 53. Recuperado el 14 de octubre de 2010 de http://hispaniasacra.revistas.csic.es.

Castillo, M. (2001). Ad Maiorem Ordinum Gloriam: Arte Retórica y Propaganda en la Historiografia Conventual de la Ciudad de los Reyes (1600-1687), Sevilla. Recuperado el 19 de setiembre de 2009 de http://www.upo. es/depa/webdhuma/areas/arte/actas/3cibi/documentos/058f.pdf

Cobo, B. (1878). Historia de la fundación de Lima. Lima: Talleres La Rosa.COOK, D. (1968). Padrón de los Indios de Lima en 1613. Lima: Universidad Mayor de San Marcos.

Chiarello, A. \& Moreno, D. (2001). Rasgos Barrocos en la génesis de los espacios públicos americanos. Recupe-

Figura 5. Apunte de apunte de la Recoleta Dominica. Fuente. Leonce Angrand. (1972).

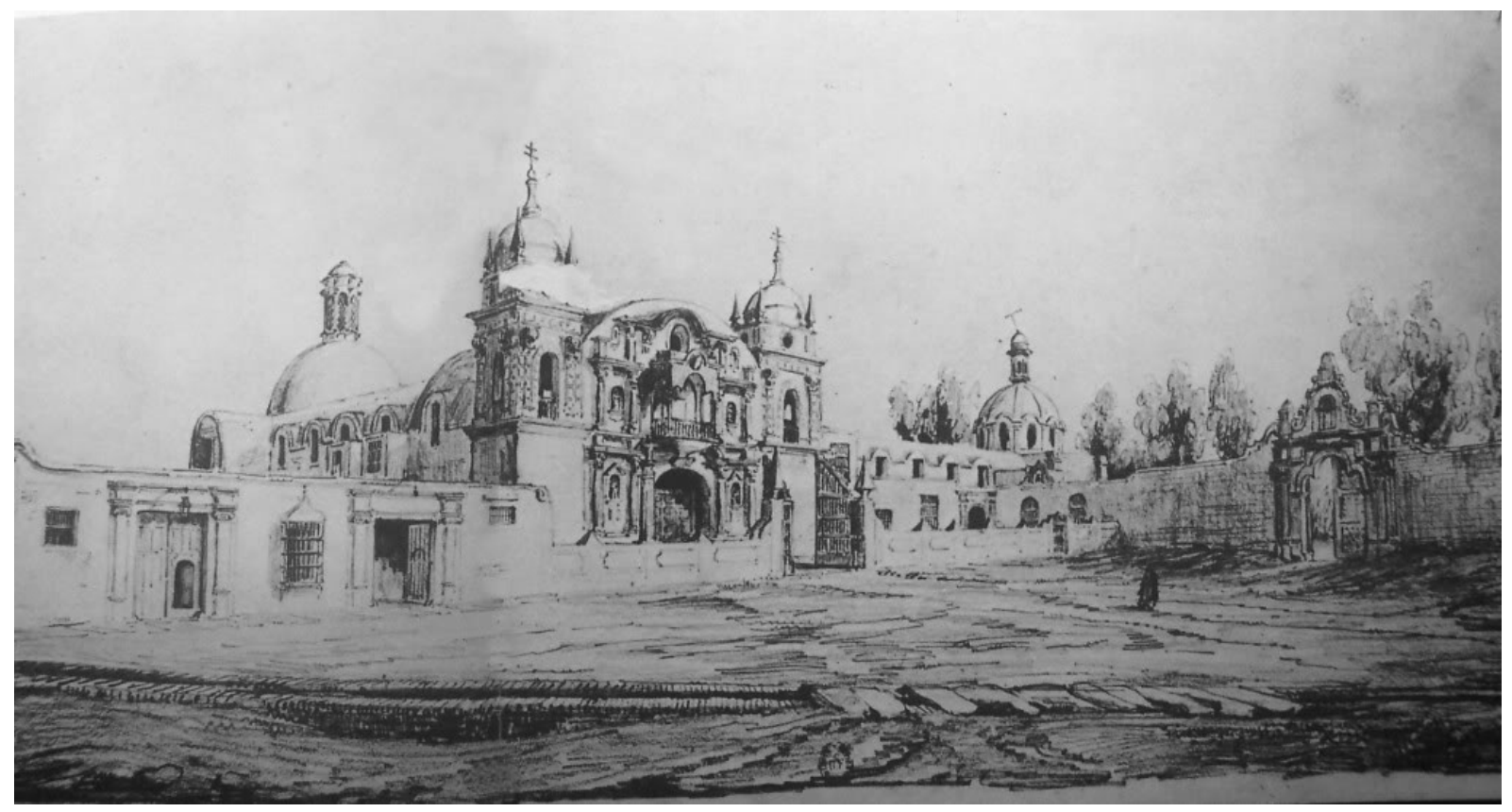


rado el 20 de setiembre de 2007 de http://www.upo. es/depa/webdhuma/areas/arte/actas/3cibi/documentos/084f.pdf

Echave, F. de (1688). La estrella de Lima convertida en Sol sobre sus tres coronas. El beato Toribio Alfonso Mogrovejo, su Segundo Arzobispo. Amberes: Editado por Juan Baptista Verduffen.

Escandón, P. (2006). La cultura barroca en indias: La visión de Mariano Picón Salas. Latinoamérica, número 042. Recuperado el 15 de setiembre de 2010, de http://redalyc.uaemex.mx/redalyc/pdf/640/64004203.pdf.

Gálvez, C. (2008). La ciudad letrada y santa: la ciudad de los reyes en la historiografía del siglo XVII. Urbanismo y vida urbana en Iberoamérica colonial, pp.71-101. Recuperado el 13 de junio de 2010, de http://www.bogota. gov.co/archivo/libreria/pdf/URBANISMO_Y_VIDA_ URBANA.pdf.

Gálvez, J. (1943). Calles de Lima y meses del año. Lima: International Petroleum.

García, A. (2004, Julio-Diciembre). Teorías del Barroco. Mañongo, Año XII, (23), pp. 209-242.

Gasparini, G. (1972). América, Barroco y Arquitectura. Caracas: (s.n).

Glave, L. (1998). De Rosa y espinas. Economía, sociedad y mentalidades andinas, siglo XVII. ( $1^{\circ}$ ed.). Lima: IEP/ BCRP.

Gonzáles, C. (2008). Barroco y Contrarreforma. Entre Europa y las Indias. Recuperado el 10 de abril de 2010, de http://www.destiempos.com/n14/gonzalezsanchez.pdf.

Gunther, J. \& Lohmann G. (1992). Lima. Madrid: Editorial Mapfre

Gutiérrez, R. (1990). Ciudades del Perú. Urbanismo durante el periodo virreinal. Estudios sobre urbanismo iberoamericano. Siglos XVI al XVIII. Sevilla: (s.n.)

Gutiérrez, R. (1992). Arquitectura y Urbanismo en Iberoamérica (2a Ed.). Madrid: Ediciones Cátedra, S.A.

Gutiérrez, R. (2001). Repensando el barroco americano. Recuperado el 19 de noviembre de 2009 de http://www. upo.es/depa/webdhuma/areas/arte/actas/3cibi/documentos/4f.pdf

Gutiérrez, R. (2008). Otros urbanismos hispanoamericanos. Memorias de la Ciudad. Urbanismo y vida urbana en Iberoamérica colonial. Caracas: Subdirección Imprenta Distrital-D.D.D.I. 51-69. Recuperado el 25 de abril de 2010, de http://www.bogota.gov.co/archivo/libreria/ pdf/URBANISMO_Y_VIDA_URBANA.pdf.

Hardoy, J. (1975). La forma de las ciudades en la América Española. Estudios sobre la ciudad iberoamericana. Madrid: (s.n.)

Kosel, A. (2008). Barroco americano y crítica de la modernidad burguesa. Anuario del Colegio de Estudios Latinoamericanos. Recuperado el 17 de noviembre de 2009,dehttp://ru.ffyl.unam.mx:8080/jspui/bitstream/10391/592/1/17_kozel.pdf.
Libros de Cabildos de Lima. Descifrado y anotado por Juan Bromley. Tomos XIV, XV, XVI, XVII (1947). Lima: Imp. Torres Aguirre.

Lohmann, G. (1996). Semana Santa de Lima. Lima: Banco de Crédito del Perú-FOPTUR.

Mannarelli, M. (1993). Pecados Públicos. La ilegitimidad en Lima, siglo XVII. (3a ed.). Lima: Centro de la Mujer Peruana Flora Tristán.

Mariategui, R. (1956). El Rímac Barrio Limeño de Abajo el Puente. Guía Histórica y Artística. Lima: Talleres Gráficos "CECIL" S.A.

Málaga, A. (1974). Las Reducciones en el Perú (1532-1600). Historia y Cultura, ( 8), pp. 141-172.

Málaga, A. (1979, Julio-Diciembre). Aspecto urbano de las reducciones toledanas. $R$. H. A, (88).

Mattos-Cárdenas, L. (1980, abril). El barroco y el desarrollo urbano en Hispanoamérica. Simposio Internazionale sul Barroco Latino Americano Roma. Istittuto Italo Latino Americano.

Mattos-Cárdenas, L. (1989). Ciudad de Dios y Ciudad Hispanoamericana: Modelos Occidentales en el urbanismo andino del siglo XVI. La Mística Spagnola Spagna America Latina. Edizione a cura di Gaetano Massa. pp.73-98.

Mattos-Cárdenas, L. (2004). Urbanismo andino e hispanoamericano: ideas y realizaciones (1530-1830). Lima: UNI - Facultad de Arquitectura, Urbanismo y Artes. Instituto de Investigación.

Meléndez, J. (1682) Tesoros Verdaderos de las Indias en la historia de la gran provincia de San Juan Bautista del Perú. Lima:Imprenta de Nicolás Ángel Tinassio.

Morris, A, (1979). Historia de la forma urbana. Desde sus orígenes hasta la Revolución Industrial. Barcelona: Editorial Gustavo Gili SA.

Mujica, R. (2002). Arte e Identidad: Las raices culturales del barroco peruano. En Banco de Crédito del Perú (Ed), pp.1-57.

Muñoz, J. (1999). El Barroco como arte plenamente moderno. Recuperado el 17 de julio

Murúa, M. (2001). Historia General del Perú. Madrid: Dastin

Odriozola, M. (1863). Terremotos. Colección de las relaciones de los más notables que ha sufrido esta capital y que la han arruinado. Colectadas y arregladas por el Coronel de Caballería del Ejercito D. Manuel de Odriozola. Lima: Tipografía de Aurelio Alfaro.

Ortiz de Zevallos, L. (1945). Curso de Evolución Urbana. Lima: Instituto de Urbanismo del Perú.

Pérez, M. (1996). Patrimonio y ciudad: el sistema de los conventos de clausura en el centro histórico de Sevilla : génesis, diagnóstico y propuesta de intervención para su recuperación urbanística. Sevilla: Fundación Fondo Cultura de Sevilla.

Porras Barrenechea, R. (1965). Pequeña Antología de Lima. Lima: Universidad Nacional Mayor de San Marcos. 
Ramón Triadó, J. (1985). Las claves del arte barroco. Barcelona: Ariel.

Ratto, C. (2009). La ciudad dentro de la gran ciudad. Las imágenes del convento de monjas en los virreinatos de Nueva España y Perú. Anales del Instituto de Investigaciones Estéticas, (94). Recuperado el 23 de agosto de 2010 de http://www.analesiie.unam.mx/pdf/94_5992.pdf.

Río, J. (2008). La Evangelización del Perú en tiempo de Santo Toribio de Mogrovejo. Lima: Biblioteca Redemptoris Mater.

Rodríguez, H. (1972). El Conjunto Monumental de San Francisco de Lima en los siglos XVII y XVIII. Boletín del centro de Investigaciones Históricas y Estéticas. Setiembre, (14).

Rodríguez, H. (1999). Manuel de Amat y Junyent y la Navona de Lima: un ejemplo de diseño urbano barroco del siglo XVIII en el virreinato del Perú. Anales del Instituto de Investigaciones Estéticas, Primavera,
$X X I$, (075), pp. 147-176. Recuperado el 15 de diciembre de 2007 de http://redalyc.uaemex.mx/redalyc/ pdf/369/36907408.pdf

Rohr, D. (2005). Ciudad y Bienes Raíces. Las Órdenes Religiosas en Lima. El Convento Dominicano (15341890). ur(b)es, II, (2), pp. 77-101.

San Cristóbal, A. (1992). Lima: Estudios de la Arquitectura Virreinal. Lima: Epígrafe.

San Cristóbal, A. (1993). La construcción de la Iglesia de la Soledad. Historia y Cultura. (22), pp. 205-241.

Venegas, C. (2005). El Vía Crucis, patrimonio intangible e historia urbana de las primeras ciudades cubanas. $P a$ labra Nueva. Pp.12-15. Recuperado el 30 de noviembre de 2009, de http:/www.palabranueva.net/contens/ archivos/6_religion/0506_1215.pdf.

Viñuales, G. (2004). El Espacio Urbano en el Cusco Colonial. Uso y organización de las estructuras simbólicas. Lima: Epígrafe. 